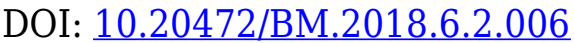

\title{
ORGANIZATIONAL SUPPORT FOR MANAGERS IMPLEMENTED BY EXTERNAL EXPERTS - RESEARCH RESULTS
}

\section{IZABELA STANCZYK}

\begin{abstract}
:
Organizational support is currently one of the key trends influencing the efficiency of management in the case of managers. Hence, it is essential for it to be taken into account in terms of the processes of improving the organization.

The aim of the herein paper is the ascertainment of the actions of external experts from the organization of advisory services which provide support for managers in their efficient management. Qualitative research was applied in order to present a more complete picture of the organizational support for managers. Two interviews were conducted with experts from external organizations rendering support for higher level managers. The information acquired during meetings indicated the direction of support rendered for managers in terms of efficient management, as well as making the gaps in the competences of managers visible, while also the imperfections in the organizations associated with the processes, procedures, or the lack of, or insufficient systems of support in terms of managerial decisions. Respondents' answers can be used in organizations that intend to implement changes. Using the interviews, it can get valuable information on the needs of managers regarding increasing their efficiency. The results of interviews can be used by HR managers, personal advisers or HR Business Partners to build organizational support projects for managers at the various levels of management.
\end{abstract}

\section{Keywords:}

organizational support, managerial efficiency, perceived organizational support, Personnel Management, Personnel Economics: Training.

JEL Classification: 124, M12, M53

\section{Authors:}

IZABELA STANCZYK, Jagiellonian University, Department of Human Resources Management, Institute of Economics, Finance and Management, Poland, Email: izabela.stanczyk@uj.edu.pl

\section{Citation:}

IZABELA STANCZYK (2018). Organizational support for managers implemented by external experts research results. International Journal of Business and Management, Vol. VI(2), pp. 90-107., 10.20472/BM.2018.6.2.006 


\section{Introduction}

The organizational support of managers is that of aid in terms of management that is rendered to managers by specialists from within and outside the organization. Such support may refer to building the appropriate relations; preparing the special programs of development for managerial competences; preparation of technological solutions that help managers in terms of managing and adjusting the organizational structures for the tasks executed by the manager and his/her team; psychological help for a manager in difficult situations; preparation of a set of tools of a controlling dimension that facilitates the planning, monitoring and inspecting the effects of work and the level of the tasks executed (Stańczyk, 2018).

A higher level manager in an organization is a member of the board, as well as the managing director (Oleksyn, 2017, p. 162), director of a division or function (Oleksyn, 2010 , p.168). These managers are key decision-makers in the organization (Hambrick, Mason, 1984) and provide the enterprise with a general direction of action (Huovinen, Pasanen, 2010). It would be constructive for the organizational support to lead to the increase in the efficiency of management by managers, particularly the high-level managers. Efficiency is defined as the ability of an organism to execute specified activities; the practical skill of executing something; the resources of news, the skills in some field (https://sjp.pwn.pl). In the theory of an organization and management, efficiency serves the evaluation of the functioning of the organization. The efficiency of management is defined as both effective and efficient actions (Tyrańska, 2011). The scientific considerations including the organizational support of managers by internal specialists in the organization have been presented in detail in the book I. Stańczyk. Organizational support of managers (2018). The organizational support of managers by experts from consulting companies is presented in this article. The aim of the article has been to present the results of the research carried out by the author among experts from personnel consulting companies. They provide organizational support from outside the organization. Using the interviews, you can get valuable information on the needs of managers regarding increasing the efficiency of their operations, which is the purpose of this study.

\section{Organizational support - theoretical notions}

At present, by considering the essence of organizational support (compare: Stańczyk, 2017), it is worth exploring the research conducted by L. McFarlane, S. and S. J. Wayne who illustrated the significance of the perception of organizational support(perceived organizational support, POS) ${ }^{1}$ as a display of the behaviour of the employed, including managers in the enterprise (Rhoades, Eisenberger, 2002). However, R. Loi, N. Hangyue, S. Foley opined that the positive perception of organizational support reduces the desire to leave the organization (Loi, Hang-yue, Foley, 2006). Thus, it is significant for organizations to take steps with the aim of ensuring their appropriate positive perception via the definition of the strategies and practices relating to human resources which refer to the needs and expectations of the employed (Tuzun, Kalemci, 2012), including high-

\footnotetext{
A thorough analysis of literature relating to Perceived Organizational Support was presented by M. GnojnyZbierowska in the paper Znaczenie postrzegania organizacji przez pracownika we współczesnych naukach o zarządzaniu (Significance of perception of an organization by an employee in modern science on management), Economic study. Scientific papers of Uniwersytetu Ekonomicznego w Katowicach, No. 306, 2016, pp.7-19;
} 
level managers. I. K. Tuzun and R. A. Kalemci prove that in order to increase POS successfully, it is constructive for managers to strive towards elaborating on the ways to increase their social support (Tuzun, Kalemci, 2012). The subject of manager support in the organization has not been often taken up in the past scientific publications. The most important researchers who are in some way affected this topic includes $\mathrm{H}$. Munsterberg, M. P. Follet, E. Mayo, who started considering the support of managers in the selection and motivation processes (Griffin, 2002); R. Eisenberger, R.Huntington, S. Hutchinson, D. Sowa - noted the importance of organizational support for increased commitment and job satisfaction (Eisenberger, Huntington, Hutchinson, Sowa, 1986); L. McFarlane, S. and J. Wayne defined the term of perception of organizational support and its impact on behavior in the organization (McFarlane, Wayne, Wayne,1993); E. E. Kossek, A. Ollier-Malaterre, M. Dean Lee, S. Pichler. D. T. Hall proposed a model to reduce the workload of managers (Kossek, Ollier-Malaterre, Dean Lee, Pichler. Hall, 2016); T.M. Amabile, E. A. Schatzel, G. B. Monet, S. J. Kramer claim that managerial support influences the creativity of the managed team (Amabile, Schatzel, Moneta, Kramer, 2004); S. Sawang notes that the level of managerial support is important for reducing the level of psychological and professional stress (Sawang, 2010). On the other hand, M. Gunkel, Ch. Schlaegel, T. Rossteutscher, B. Wolff argue that managerial support affects the emotions of employees (Gunkel, Schlaegel, Rossteutscher, Wolff, 2015); M. Carrrol and M. Walton believe that the essence of support is consultancy (Carrrol, Walton, 1997); L. MacFarlane Shore, L. E. Tetrick, who conducted the research, said that the support of managers from the specialists from the organization is expected, which translates into the level of achieved results (MacFarlane Shore, Tetrick, 1991); A. Torun presents the need to support managers in professional development (Torun, 2013). G. C. Williams, H. Halvari, Ch. P. Niemiec, Øystein Sørebø, A. H. Olafsen, C. Westbye draw attention to the level of managers' autonomy (Williams, Halvari, Niemiec, Øystein Sørebø, Olafsen, C. Westbye, 2014). On the basis of Polish science, the support of managers is described, among others, by M. Bugdol, who emphasizes the importance of justice (Bugdol, 2014), B. Kożusznik draws attention to organizational behavior (Kożusznik, 1994); D. Turek and I. Czaplińska focus on the appropriate support regarding the creation of specific working conditions (Turek, Czaplińska, 2014) and B. Gajdzik points to the appropriate relations in the organization (Gajdzik, 2012).

A division of the dimensions of organizational support for managers was prepared, which includes psychological support, while also relational, controlling, structural, educational support, as well as support of the systems aiding the managerial decisions. Simultaneously, elements influencing managerial support were indicated, among which the following were specified: motivation of the organization, psychological contract, formation of ties and organizational behaviour ${ }^{2}$.

\section{Methodics of research}

The aim and subject of this research has been to examine how organizational support provided by experts from personnel consulting companies looks like. The study has included a literature's review and empirical analysis of interviews conducted with experts from consulting companies. The information contained in the literature analysis

\footnotetext{
2 A detailed description of the dimensions of the organizational support and the definition of the elements influencing managerial support was presented in the following: I. Stańczyk, Wsparcie organizacyjne menedżerów (Organizational support of managers), Wydawnictwo Uniwersytetu Jagiellońskiego, Kraków 2018
} 
was used for the interviews and on this basis an original questionnaire for experts was prepared. Qualitative research has been applied in the herein paper which analyses and interprets the significance of what a unit or group attributes to the problem under research (Creswell, 2013). The chosen research method was by interview that was partially structuralized.

Each test consists of the following parts. The first concerns the illustration of the environment from which the consultant comes from. They were marked $\mathrm{O} 1$ and $\mathrm{O} 2$. The second is an interview with a person who is a representative of a consulting company. Interviews were carried out by the author. The presented research results are the author's own work.

In order to present a more complete picture of the organizational support of managers, two interviews $(\mathrm{O} 1, \mathrm{O} 2)$ were conducted with experts from external organizations providing support for higher-level managers. The testing scheme is shown in Figure 1.

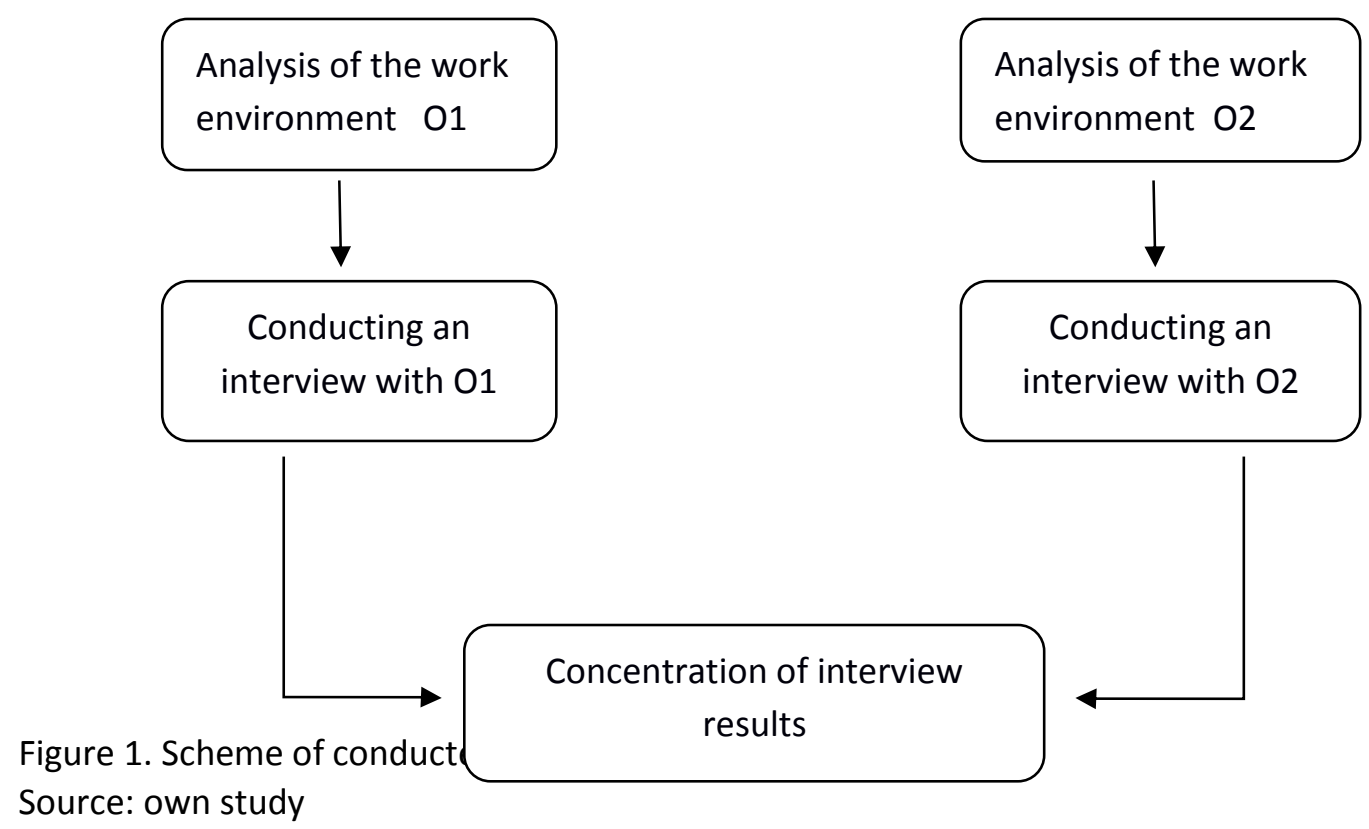

The information acquired during meetings indicated the direction of the support provided for managers in terms of efficient management, as well as making the gaps in terms of the competences of managers visible, while also the imperfections in organizations associated with processes, procedures, or the lack of or even insufficient systems of support for managerial decisions. The selection of these organizations was deliberate and influenced by work executed with managers at higher levels of management, as well as the variety of offers of support in terms of efficient management and taking strategic decisions. The interviews with the experts constitute a supplement to the opinion polls carried out among higher-level managers in enterprises. The project of comprehensive research has been presented in Monograph I. Stańczyk „Wsparcie organizacyjne menedżerów" (Organizational support of managers, 2018). 


\section{Interviews with experts from consulting companies}

\subsection{Interview with an 01 expert}

The first interview was conducted with Mrs. Elżbieta Mądra ${ }^{3}$ - an Interim Manager (IM) for 10 years and associated with the Society of IM.

\section{Analysis of the work environment}

Interim management ${ }^{4}$ is a temporary action within the organization that is defined in terms of the aim and the scope of action which is executed by an entity (Interim Manager) who is geared towards the achievement of specific established business results and is based on cooperation and participation with regard to risk and profit in terms of the intended effect. ${ }^{5}$

The firm INWENTA Sp. z.o.o. is the precursor of specialized interim projects on the Polish market and has been in existence for 9 years. It cooperates with local and foreign organizations associated with Interim Managers. Their strategic partner is the British association known as the Institute of Interim Management (IIM). The characteristic feature of activities is the rapid adjustment of the appropriate Interim Manager to the managers requiring support in various types of organizations, which also frequently relates to actions executed by the Shadow Manager. This organization, together with the Society of Interim Managers (SIM) prepared specialized methodics and tools for the Interim Managers. SIM is the only non-profit organization on the Polish market that converges Interim Managers. It was established in 2009 and since 2016 it has been operating as the Regional Association Group in among other places, Katowice, Lublin and Poznań. Its aim is that of public activities on behalf of building and promoting the notion of time management. The members of the Society of Interim Managers share their knowledge and experience, while also acting on behalf of increasing the qualifications of the managerial staff. ${ }^{6}$ The work of Interim Managers is based on specially prepared methodics of conducting projects. Its levels have been illustrated in the following table.

\footnotetext{
Interview conducted in April 2017 during the meeting of the Board of SIM in Warsaw. The elaboration of this case study involved the utilization of materials provided by the firm Inwenta which cooperates with SIM.

$4 \quad$ Interim Management emerged in the 1970s in the Netherlands as a means of escaping the very restrictive labour law which imposed the obligation on the employers to pay high severance packages to employees made redundant. Managers who were certain of their high value on the market agreed to work for a higher fee for a specified period of time or for the duration of the execution of a specified task, while simultaneously giving up employee protection rights as guaranteed by labour law. This solution was a win-win for both parties: in the case of the employer, despite the higher individual fees, they did not have to pay severance packages and had a guaranteed result for which they hired an interim manager, who in turn had higher remuneration for his/her high competences and participation on the business market of the employer. The case of the Netherlands broke the hitherto stereotype of the work of a manager. However, if it had not been for the objective demand for this type of service on the market, the formula of interim management would have remained merely a way to sidestep labour law in only one country . Collective work of M. Buchajska-Wróbel, K. Gajda, J. Gasparski, E. Rytka, R. Wendt, Warszawa 2010 - materials provided by Association of Interim Management.

5 Interim Management - Novelty in management of age and the company- special edition - materials provided by Association of Interim Management.

$6 \quad$ Interim Management - Novelty in management of age and the company- special edition - materials provided by Association of Interim Management.
} 
Table 1. Methodics of IM project

\begin{tabular}{|c|l|}
\hline LEVEL & \multicolumn{1}{c|}{ CHARACTERISTICS } \\
\hline project-based & $\begin{array}{l}\text { - based on methodics of Interim Management prepared within the } \\
\text { framework of the project entitled: "Interim Management }- \text { a novelty } \\
\text { in management of a firm and age" } \\
-\quad \text { tools: sheet of cost and benefit analysis; plan of action and } \\
\text { monitoring of effects; protocol of results of project }\end{array}$ \\
\hline meritorical & $\begin{array}{l}\text { HR etc.), as well as specifics of the organization } \\
-\quad \text { the products of the project are created at this level }\end{array}$ \\
\hline
\end{tabular}

Source: Self-analysis on the basis of Inwestycja w kapitał ludzki z Interim Managerem (Investment in human capital with an interim manager) - materials provided by the firm INWENTA Sp. z.o.o.

Interim management is based on design employment. As stated by M. Buchajska Wróbel, the vice-chairman of SI in referring to the German research: "In 10 years over $60 \%$ of the market shall involve design employment and this is a global trend from which there is no return?.

The areas of activities of IM are most frequently as follows (materials provided by the firm INWENTA Sp. z.o.o.):

- $\quad$ Restructuring of enterprise;

- $\quad$ Preparation for changes to the ownership structure of the enterprise;

- $\quad$ Creation of new perspectives for the development of the organization;

- $\quad$ Building a professional team for the realization of a specific project;

- $\quad$ Crisis situations;

- $\quad$ Building and implementing new structures that are essential for the execution of new tasks that have not been executed by the organization up to now;

- $\quad$ Necessity of replacing an absent manager (illness, leave, training);

- $\quad$ Support (shadow management) of a specific manager with expert knowledge and experience.

Benefits for managers from cooperation with an Interim Manager (materials provided by the firm INWENTA Sp. z.o.o.):

- $\quad$ Acquisition of business knowledge and expertise;

$7 \quad$ Interim Management - Novelty in management of age and the company- special edition - materials provided by Society of Interim Management. 


\section{- Availing of experience in the management of an enterprise and experience of the sector;}

- $\quad$ Added value which remains in the organization after completion of cooperation: development of managers; instilling new efficient methods of work; advisory services relating to the planning of succession, etc.;

\section{- $\quad$ Significant saving of time and money which would be necessary outlays for retraining and employing a new employee on the basis of an employment contract; \\ - $\quad$ Lack of financial and social insurance burdens within the framework of an employment contract;}

- $\quad$ Flexibility and rapid accessibility to the resources of knowledge and experience.

Research relating to IM has been conducted in Poland for several years. According to a report executed by the Society in 2016, it is possible to analyse the development of the IM market ${ }^{8}$. Working as an IM requires great experience in the transformation processes in organizations of various types, thus the age of the people executing this type of project usually begins from 40 years of age. The majority of projects $(69 \%)$ are conducted by people aged 40-59 years old, albeit the duration of the projects in the majority of cases amounts to 6 months (Wendt, Niesiobędzka-Rogatko, DziewitGontowska, 2016).

However, in the case of Interim Managers "the average remuneration fee oscillates around 2,000 - 2,300 PLN. The scale of payment per day ranges between 750 and 4,300 PLN. The lowest rate, up to 1,250 PLN relates to projects acquired by means of tenders or projects executed by interim managers commencing their careers in this formula. The highest rate, over 4,000 PLN daily relates to the level of top managers, senior interim managers with many years of universal managerial experience and with a large portfolio of successfully executed projects). Almost $50 \%$ of projects are large in terms of the project value, which may result from the fact that the managers of various organizations need great support in management and are willing to pay sums of money in excess of 350,000 PLN" (Wendt, Niesiobędzka-Rogatko, Dziewit-Gontowska, 2016).

The greatest support is provided for organizations from the manufacturing sector, machine industry, IT and telecommunications, services for enterprises, retail trade and financial services. However, the areas of support have most frequently been activities of operational solutions in the organization, $\mathrm{HR}$, general management, production and logistics.

\footnotetext{
$8 \quad$ Research conducted in the period of March-November 2016 was based on 246 projects executed and encompassed a group of 111 respondents (a growth of $184 \%$ within 5 years). It is worth noting that the environment of interim managers in Poland is currently estimated at approximately 1,500 people conducting this profession. By comparison, in Great Britain approximately 20,000 managers work on an interim basis, while around 15,000 in Germany. The market of IM in Germany over the past five years has grown at an average of almost $20 \%$ year on year. In 2017, further growth of around $15 \%$ is expected. According to the predictions for the current year, the German market of IM shall exceed the threshold of $1.8 \mathrm{bn}$ Euros. A similar level of over $1.7 \mathrm{bn}$ pounds was attained by the British market three years ago, which has been showing stable growth of around $8-10 \%$ annually. Wendt R., Niesiobędzka-Rogatko K., Dziewit-Gontowska U. Interim Management w Polsce (Interim Management in Poland). Report from research executed in 2016 by Association of Interim Managers - materials provided by Association of Interim Management.
} 
In analysing the detailed information presented by people working in the Society of Interim Management, it is worth presenting the specific activities of several Interim Managers, which are illustrated in Table 2.

Table 2. Examples of activities of Interim Managers

\begin{tabular}{|c|c|}
\hline AREA OF SUPPORT & ACTIONS UNDERTAKEN \\
\hline $\begin{array}{l}\text { Restructuring in capital } \\
\text { group }\end{array}$ & $\begin{array}{l}\text { The task was to support the management in the radical } \\
\text { reduction of costs in all companies within the framework } \\
\text { of the Capital Group, prepare a new strategy, rebuild the } \\
\text { organizational structure and restructure the employment } \\
\text { system. The process lasted } 2 \text { years and the effect of } \\
\text { stabilization in the organization was achieved, as well as } \\
\text { the profitability of the organization and the increase in } \\
\text { share value. }\end{array}$ \\
\hline $\begin{array}{l}\text { Implementation of system } \\
\text { of management by aims }\end{array}$ & $\begin{array}{l}\text { Help the chairman to designate goals and support the } \\
\text { chairman in the process of informing the employees with } \\
\text { regard to the implementation of this solution }\end{array}$ \\
\hline $\begin{array}{l}\text { Strategic analysis in a } \\
\text { trading company }\end{array}$ & $\begin{array}{l}\text { This analysis indicated dependence on one client, a lack } \\
\text { of pro-sales function, growing dissatisfaction of } \\
\text { employees - actions undertaken such as renegotiation of } \\
\text { sales agreements, implementation of production of } \\
\text { simple products, creation of sales functions from the very } \\
\text { beginning, activation of trading activity, preparation and } \\
\text { implementation of a motivational system of } \\
\text { remuneration, as well as renegotiation of credit } \\
\text { agreements }\end{array}$ \\
\hline $\begin{array}{l}\text { Support by organizational } \\
\text { changes }\end{array}$ & $\begin{array}{l}\text { Actions associated with strengthening the organizational } \\
\text { culture and leadership skills }\end{array}$ \\
\hline $\begin{array}{l}\text { Increasing the work } \\
\text { efficiency and reduction } \\
\text { of costs }\end{array}$ & $\begin{array}{l}\text { Implementation of changes with the specific approach of } \\
\text { the management of the organization as an observer; a } \\
\text { key element has become the stipulations of the } \\
\text { agreement on cooperation and activation of the } \\
\text { management as the guarantee of the success of the } \\
\text { changes }\end{array}$ \\
\hline $\begin{array}{l}\text { Conducting process of } \\
\text { restructuring }\end{array}$ & $\begin{array}{l}\text { Application of outsourcing of financial and bookkeeping } \\
\text { tasks }\end{array}$ \\
\hline $\begin{array}{l}\text { Launching activities of } \\
\text { theme park - creation of } \\
\text { strategic plan }\end{array}$ & $\begin{array}{l}\text { Acquisition of appropriate permits, construction } \\
\text { supervision and support in the acceptance testing of the } \\
\text { building, as well as acquisition of equipment and }\end{array}$ \\
\hline
\end{tabular}




\begin{tabular}{|l|l|}
\hline & $\begin{array}{l}\text { accreditation of the UDT (Office of Technical Supervision } \\
\text { and DTR (Operation and Maintenance Manual). }\end{array}$ \\
\hline $\begin{array}{l}\text { Ensuring the survival of } \\
\text { an organization in } \\
\text { circumstances of forced } \\
\text { organizational change } \\
\text { and their consequences } \\
\text { and revitalization, as well } \\
\text { as ensuring long-term } \\
\text { profitability at a rationally } \\
\text { assumed level }\end{array}$ & $\begin{array}{l}\text { As a result of the emerging resistance to the proposed } \\
\text { changes by the IM, one of the tasks was to integrate } \\
\text { people with regard to the assumed goal and create the } \\
\text { appropriate procedures of communicating about changes }\end{array}$ \\
\hline
\end{tabular}

Source: Self-analysis on the basis of Interim management w Polsce. Jak zyskać nieograniczony dostęp do know-how z najwyższej półki (Interim Management in Poland. How to gain unlimited access to know-how of the highest level). Collective work by M. Buchajska-Wróbel, K. Gajda, J. Gasparski, E. Rytka, R. Wendt, Warszawa 2010 - materials provided by the Association of Interim Management.

With regard to such a varied set of activities illustrated in Table 2, an Interim Manager must possess the skill of applying a multitude of tools which help him/her in the attainment of the assumed goal. These are orders issued, as well as motivating and supporting, coaching, advice, training, negotiations or persuasion (Buchajska-Wróbel, Gajda, Gasparski, Rytka, Wendt, 2010) . Hence, an Interim Manager must possess key features such as the following: communication, efficiency of action, as well as knowledge and experience, confidence in himself/herself and in their own possibilities, project approach, self-discipline, skill of coping with stress, skill of rapid adaptation to a new environment (Buchajska-Wróbel, Gajda, Gasparski, Rytka, Wendt, 2010). The activities stipulated in the afore-mentioned table display that it is primarily support of higher-level managers and it relates to strategic activities in the organization. The detailed illustration of the functioning of Interim Managers presented was to first and foremost indicate the amount of work executed in this sphere. Secondly, it indicates what large financial outlays are incurred by organizations in order to streamline the efficiency of action of the managers already employed. The projects executed indicate what problems are encountered by managers in higher positions and despite the appropriate education and preparation for the fulfilment of the managerial role at such high positions, they have problems with diagnosing and executing the assumed changes. It may be concluded from the material provided by SIM that there is an increasing demand for this type of support. It is chosen after a preliminary diagnosis of the problem in a particular organization. As is also evident from the material presented, the Interim Manager must possess great multi-dimensional experience in terms of the transformation of organizations in several areas that usually takes place simultaneously.

\section{Analysis of the interview with 01}

This is attested to by the information acquired during the interview conducted with Mrs. Elżbieta Mądra. She enumerates such areas as follows: the reorganization of an 
enterprise, sales support, implementation of controlling tools and the launching of a new product. These are activities conducted together with managers of higher levels where strategic decisions are taken. Our interlocutor also indicated the great "objectiveness of the Interim Manager who reacts to problems emerging outside the organization and is not involved emotionally". The research participant underlines that she increasingly works with Polish organizations which "want to become professional and develop". The projects executed by Mrs. Elżbieta Mądra primarily related to providing support for holistic management in the "division of tasks, aid in the structurization of the organization, preparation of the structure of reports, implementation of procedures and instructions". Cooperation in this field is with "people managing organizations, thus owners, general directors, managing directors, albeit in larger enterprises department heads. This is frequently individual work at the request of the managing staff, in some ways on their behalf and with the key employees of an organization. More and more frequently support for a manager takes on the form of Shadow Management where I accompany a manager in the everyday managerial tasks".

As indicated by the interviews conducted, managers rather expect ready-made solutions that help them to streamline their work, or to implement the intended changes. These solutions relate to the so-called "hard" aspects of management, namely the finished processes, procedures and forms of proceedings. Likewise, they increasingly relate to the "soft" elements associated with building the appropriate relations within the organization, improvements in communication, while also skills in coping with conflict. According to our interlocutor, "Our managers already possess great knowledge and managerial skills which were not so widespread several years ago. However, there is evidence of a constant need to supplement this with the so-called soft skills. In as much as the operational tasks, familiarity with the sector, professional environment have all become very familiar in areas such as motivation, building the development of employees and running teams, albeit there is still much to do. The creation of openness in terms of building a business culture is often a challenge, particularly in Polish organizations". Mrs. Elżbieta Mądra draws attention to an element in the behaviour of a higher-level manager that is very difficult to observe with regard to his/her isolation. She claims that "the openness of managers emerges as a result of the isolation of a manager and sometimes telling someone about undertaking action in a particular area causes the reinforcement of the decision or actually its very undertaking. This perfectly illustrates how important building and maintaining professional relations really is".

An example of support for a higher-level manager may be the contribution to the efficient organization of work, as well as efficient and effective management on the international market, namely the implementation of managerial tools in a micro-scale organization: a Polish branch of a foreign services organization. "A great challenge for a manager was the creation of a functional organizational structure with multi-task positions in such a way as for the tasks facing the organization to be executed. It is a frequent case on our market whereby the owners expect a minimum employment structure, universality of employees, particularly when they are commencing business activities. With really great determination the manager was able to build an effectively functioning organization within three months in which the division of tasks and simple managerial tools began to bear fruition. Each of the employees dealt with their areas of competences successfully in cooperation with their colleagues from abroad. The success involved the fact that the manager devoted as much time to his colleagues as they required at the beginning of the implementation: he explained what he expected, how he sees it, while also explaining the expectations of headquarters. Responsibility was cleverly shared out 
among all the employees and after three months they felt like the owners of the processes and operated in their "small kingdoms". Work on the success of the manager involved the provision of tools for the division of tasks and reporting, while also instructions about conducting talks and meetings with the team".

Our interlocutor drew attention to the fact that "managers frequently forget about a simple principle: the return on capital. The capital of a manager is his/her time and money. If you build an organization and devote time to the team, this shall bear fruition in terms of a return by the achievement of results for the whole organization".

In summing up the interview with Mrs. Elżbieta Mądra, it is worth drawing attention to the perceived managerial problems of higher-level managers. They relate to the types of organizational support described in the monograph.

\subsection{Interview with an 02 expert}

The second interview was conducted with Mr. Robert Reinfuss ${ }^{9}$, who is a business advisor with over twenty years of advisory experience and twelve years of experience in management in various market sectors such as the following: manufacturing and trading enterprises, or banks.

\section{Analysis of the work environment $\mathrm{O2}$}

He specializes in audits and creating personnel policies; increasing the effectiveness of the organization; implementation of participatory management systems, as well as the remuneration and motivational policies for medium and large scale organizations in Poland. He is also the author of the following books: „MBO prosta skuteczna technika zarządzania Twoją firmą" (MBO- a simple effective technique for managing your firm), „Rynek celów. Zwrot z inwestycji w HR” (Market of objectives. Return on investment in $\mathrm{HR}$ ), as well as numerous articles in such magazines as Personnel Plus, Personnel and Management, Benefit, Outsourcing Magazine, THINKTANK, Puls Biznesu. With both his education as well as advisory and business practice he has conquered the markets of Poland and Western Europe. The prevalent theme of both the publications, as well as his advisory services of Reinfuss is that of the efficiency of organization. He advocates several managerial methods and techniques applied in the economies of Western Europe: management by objectives (MBO), managerial and employee participation (Market of objectives), as well as the techniques of measuring and increasing the profitability of work (Value View). Within the framework of these methods the tasks executed by employees are analysed and subsequently verified from the viewpoint of their usefulness for the organization. Tasks of high profitability levels that are worth investing in are indicated. The quantitative results of indicators are presented which facilitates the reallocation of resources. Reinfuss, together with his team, executes advisory projects for international corporations, state-owned enterprises, as well as for Polish-owned organizations. As indicated in the interviews conducted, projects are run "for owners and boards of directors, HR directors, albeit more seldom for higher-level managerial staff. The managerial staff commissions the help of advisors very sporadically. The basic reason is the lack of budgets. A second important reason is the lack of tradition for such aid in Poland. The projects of support for the managerial staff are most often commissioned from higher levels and frequently executed in spite of the participants- beneficiaries". 


\section{Analysis of the interview with $\mathrm{O2}$}

According to the consultee $\mathrm{O} 2$ "Both those in charge and managers do not usually know what support they may expect from external advisors. External services are most frequently associated with training. In the case of large enterprises external services are most frequently associated with the execution of projects for which the organizations do not have the internal competences, or which they do not desire to do so themselves, for some reason, e.g. restructuring processes. The expectations of clients are varied drastically and it is difficult to find any regularities here. There is a prevalence of a lack of knowledge on the issue of how to avail of external advisory services. I have clients who expect personal advisory services in management. This is a form of mentoring which is usually conducted over a long period of time. Some clients expect the realization of their own plans and actions. These are for instance, implementation or training projects. Some clients prefer to rely on the knowledge and experience of the consultant. This first and foremost relates to projects within the framework of which specific products are launched, of the type of market of objectives, Value View, replacement program, building of strategy, standardized training products, etc. Clients understand their involvement in advisory projects in various ways. There are those who after signing the agreement, withdraw from the work of the consultant by assuming that they are paying to get the issue off their hands. There are others who want the projects to be executed under their strict supervision and demand their participation at every stage. The theme of advisory projects is very wide. Those in charge and managers require and search for support in all matters where they have problems, including personal problems. However, what is characteristic is the fact that there is still a lack of awareness of who can help them and in what area. The search for help, or rather call for help is therefore received by random people or enterprises. The selection of advisors is dominated by the criteria of personal relations and not expertise". As noted by R. Reinfuss, "Polish organizations are very seldom interested in providing external support for their managers. Advisory services most frequently serve the shaping of the attitudes of managers and employees, or providing them with knowledge which is important to the organization or ordering party, but not the participants. These services, together with training courses frequently arouse negative reactions among the participants and are not perceived by them as support. I must admit that it is very difficult to change the attitude of clients towards the objectives of external advisory services. I often have the feeling of doing things without a business justification. From what I hear, training organizations and coaching organizations have even bigger problems. In executing projects for a particular organization we expect the involvement of the managerial staff, however, according to our interlocutor "managers, albeit slightly forced to participate, most frequently join in the project work. In contrast to those in charge, they do not expect ready-made solutions, but want to be co-creators. As long as the process is creative and inspiring, there is no problem with the involvement and creativity. The problem almost always starts when it appears that the change which we are planning is to really happen. As I deal with serious changes in organizations, the resistance of the managerial staff is an important factor of success or failure in my view". With regard to the issues of the competences of the managerial staff and the efficiency of management, $R$. Reinfuss states that "In Poland the managerial staff has sufficient and frequently excessive level of competences. Of course there are exceptions. By the excessive level of competences, namely over-potential, I understand the situation whereby an employer is unable to avail of the desire, qualifications and involvement of 
the manager. The cause of the over-potential is on the one hand, the high level of competences of the employee, while on the other hand, the excessively low level of expectations or other barriers to efficiency. In the situation of the over-potential of an employee, a manager has the feeling that his involvement and possibilities are not fully availed of, or are in fact wasted. In Polish business, efficiency and involvement are not restricted by the lack of competence. The most frequent restrictions that I encounter are as follows: the lack of possibility of action, space for development and involvement. The reasons for such a state of affairs are complex. The most important ones are the lack of trust that is shaped by history (everything is decided by the owner or boss), paternalism in the relations of supervisor-subordinate that is reinforced by the systems of evaluation and the so-called 'motivational systems', dramatically low level of innovations (we constantly do the same), while also the outdated culture of the directive management, manual and reactive management. Of course, in various organizations these reasons are dispersed. There are naturally competences, which if increased would improve the efficiency of management. These are most frequently independence and courage in terms of taking decisions and assertiveness. Likewise, there is also a lack of leadership competences, but I treat this more as an effect of other phenomena (e.g. the style of management of the owner) rather than a root cause. The shaping of leadership competences of the medium-level managerial staff would not have an impact on the increase in efficiency in the majority of organizations that I know". An interesting claim is that the managerial staff in Poland is not taught how to receive or used to receiving support from external consultants. There is a binding principle that everyone copes as best they can and tries to prove that this is the best it can be. Simultaneously, relatively large amounts of money are designated towards training and the so-called "motivational systems". Managers during the course of a project and even more so after its completion, count on help from advisors in exceptional cases. What is surprising is the fact that they are most frequently excellent managers with great knowledge and an instinct for business". Our interlocutor also indicated the obstacle to the efficiency of organizations that are "associated with the following: (1) poor allocation of resources people do not do what pays the most for the organization, (2) the lack of innovation and space for development, (3) over-employment, (4) the lack of mutual trust and excessive proceduralization, (5) faulty premium systems. Hence, the approach to advisory services and the expectations of advisory organizations are changing. A solution is the regular application of modern tools of stimulating efficiency, namely demand for work, involvement and competences. Such solutions include the following, among others: (1) measurements of the profitability of work and programs of the reallocation of resources (e.g. Value View), (2) programs of creativity and ambitious aims defined together with managers (e.g. the Market of objectives), as well as (3) correct planning of resources (e.g. replacement programs). Advisory organizations are increasingly required to have familiarity with these techniques and apply them. The business demand with relation to advisory services is changing. It is increasingly more seldom to connect the multiplication of goods and increase in potential of the organization, while this increasingly relates to improvement of the profitability of work and the profitability of the organization, namely the business effects".

In summing up the interview, it is worth noting that managers do not possess welldefined autonomy for undertaking action, while there is also a lack of possibility of interesting solutions for professional development in terms of which elements have an impact on the efficiency of management and the effects achieved, while also reducing the level of involvement. Likewise, our interlocutor indicated the low level of trust evident 
in organizations, little evidence of the possibilities of gratification or acknowledgement of innovative solutions. The large amount of financial outlays on the advisory services rendered were also highlighted, as well as the preparation of projects increasing the efficiency of the organization. In enterprises there is insufficient knowledge of the possibilities of external and internal support and managers are forced to act alone, which causes excessive burden in terms of the amount of tasks to be executed, as well as burden associated with the psyche of coping with problems - sometimes completely unnecessarily.

\section{Diagnostic conclusions}

The summary of the interviews' content with experts from personnel consulting companies was based on the division of organizational support for managers into its dimensions and factors affecting the support mentioned above. In terms of psychological support, in the analyzes carried out by the author, it was indicated that the most important are:

(O1);

there is a need for support in "creating openness in building business culture"

- $\quad$ support of manager in his/her "isolation" while taking difficult decisions (O1);

there is a need for support for managers relating to their personal problems and those of employees $(\mathrm{O} 1, \mathrm{O} 2)$.

In the area of relational support the research have shown:

- $\quad$ involvement is bipolar (a lack of involvement, or total involvement in each stage of the implementation of the project) $(\mathrm{O} 1)$;

- frequently the selection of an advisor is dominated by the criteria of personal relations and not expertise $(\mathrm{O} 2)$.

And in controlling support relies on:

- $\quad$ aid in defining $\mathrm{MBO}(\mathrm{O} 1, \mathrm{O} 2)$;

- $\quad$ creating strategic analysis $(\mathrm{O} 1)$;

- $\quad$ increasing the work efficiency and reduction of costs (O2);

- $\quad$ necessity of applying the tools of stimulating efficiency (O1).

As research has shown, the actions taken by experts regarding structural support most often consist of:

- $\quad$ support in the structuring of the organization in the form of reporting, implementation of procedures and instructions (O1);

- $\quad$ aid in designating goals for the team (O2);

- $\quad$ creating procedures of communicating about changes with employees (O1);

- $\quad$ creating processes of restructuring the enterprise (O1). 
As part of the support for systems of decision-making, experts propose to use: Methodics of Interim Management (O1) and management by goals: "Market of goals", "Value View" (O2). Educational support, however, should be directed at: support in conducting an enterprise (O1), advisory services in the structuring of the enterprise (O1), Shadow Management (O1), mentoring (O1, O2), advisory services in management $(\mathrm{O} 1, \mathrm{O} 2)$, standardized training products $(\mathrm{O} 2)$.

Within the framework of summing up the information collected during the course of interviews with external experts, an analysis of the factors supporting managers in an organization was also conducted. As part of organizational motivations, according to experts, it becomes important:

meeting of external experts with managers in accordance with the accepted schedule for the given project $(\mathrm{O} 2)$;

- continuity of work with the manager within the framework of Shadow Management (O1);

- utilization of mentoring in terms of increasing the professional competences of the managers $(\mathrm{O} 2)$;

- $\quad$ a motivational system is adjusted to the medium-level $(01,02)$;

- a high possibility of increasing competences - individual meetings of the manager and the expert are applied (O1);

- $\quad$ according to the opinions of experts, there is a principle that is binding in the work of a manager, namely "everyone copes how he/she can and tries to prove that this is the best it can be" (O2).

The psychological contract is based on: expectations on the part of experts with regard to the managers are as follows: involvement, adherence to the established principles of cooperation, trust $(\mathrm{O} 1, \mathrm{O} 2)$ and expectations on the part of managers with regard to the experts are as follows: understanding, ethical behaviour, involvement and trust (O2). As for the essence of relationships in the organization are: depending on the expectations of the project designers, formal ties are created (mainly on the basis of entries into the agreement on cooperation), (O1) and cooperation based on trust; flexibility of actions $(\mathrm{O} 1, \mathrm{O} 2)$. Organizational behavior is depending on the project executed, the work is to provide ready-made solutions, but very frequently teams are appointed to solve a particular problem and prepare further action( $\mathrm{O} 1, \mathrm{O} 2)$, rapid availability of knowledge resources of experts and their professional experience $(01,02)$ and system of communication prepared individually for a project usually encompasses the information that is necessary for effective management which is transferred on an ongoing basis $(\mathrm{O} 1, \mathrm{O} 2)$. Barriers to managerial work according to the perceptions of external experts are above all:

- $\quad$ lack of information among managers as to who can help and in what area within the organization $(\mathrm{O} 2)$;

- $\quad$ insufficient support within the organization in the sphere of dealing with a conflict situation or in crisis management $(\mathrm{O} 1)$;

- $\quad$ insufficient support in the field of personnel advisory services $(01,02)$; 
- $\quad$ lack of sufficient psychological and systemic support $(\mathrm{O} 1, \mathrm{O} 2)$;

- $\quad$ isolation of the manager at the moment of taking unpopular decisions $(\mathrm{O} 1$,$) ;$

- $\quad$ insufficient control of the execution of tasks in accordance with the principles and regulations $(\mathrm{O} 1)$;

- lack of familiarity with the possibilities of acquiring external support in the particular organization $(\mathrm{O} 1, \mathrm{O} 2)$;

- $\quad$ insufficient competences in the areas of motivation, building development of employees, conducting teams, building the appropriate organizational culture by taking the business approach into account $(\mathrm{O} 1, \mathrm{O} 2)$;

- $\quad$ in the case of managers, the lack of possibilities to take action, space for development and involvement $(\mathrm{O} 1, \mathrm{O} 2)$;

- $\quad$ excessively low level (specified by the management/owners) of possibilities of independent decisions (specified by the management/owners) $(01,02)$;

- low level of courage in taking decisions (frequently not so popular ones) and assertiveness $(\mathrm{O} 1)$;

- $\quad$ lack of well-honed leadership competences $(01,02)$;

- $\quad$ there are unadjusted premium systems for the requirements of the particular organization, which reduces the management efficiency of the managers $(01,02)$.

The perception of HR support in the organization by external experts is also interesting. Experts represent the organization in the field of personnel advisory services and according to them this support is actually missing, as managers often do not know to whom they should turn to in the organization with a particular problem $(\mathrm{O} 1,02)$.

The interviews presented and their analysis of the dimensions and factors of organizational support for managers may be the beginning of deeper research. The results achieved may be the basis for building appropriate organizational support programs for managers in various types of organizations.

\section{Reference}

Amabile T. M., Schatzel E. A., Moneta G. B., Kramer S. J. (2004), Leader behaviors and the work environment for creativity: Perceived leader support, The Leadership Quarterly 15, p.5-32. https://doi.org/10.1016/j.leaqua.2003.12.003

Badania jakościowe. Metody i narzędzia (2012) (red.) D. Jakiemielniak D., tom 2, Warszawa, s.113

Buchajska-Wróbel M., Gajda K., Gasparski J., Rytka E., Wendt R., (2010) Interim management w Polsce. Jak zyskać nieograniczony dostęp do know-how z najwyższej półki. Warszawa 2010 - materials provided by the Interim Management Association

Bugdol M. (2014) Znaczenie sprawiedliwości w zarządzaniu ludźmi. Dlaczego warto być sprawiedliwym, Difin, Warszawa, p. $181-200$. 
Creswell J. W. (2013) Projektowanie badań naukowych. Metody jakościowe, ilościowe i mieszane, Wydawnictwo Uniwersytetu Jagiellońskiego, Kraków, s. 30-41

Eisenberger R., Huntington H., Hutchinson S., Sowa D. (1986) Perceived Organizational Support, Journal of Applied Psychology, Vol. 71, Nr 3, 500-507. https://doi.org/10.1037/0021-9010.71.3.500

Gajdzik B. (2012) Poziom zaangażowania pracowniczego w przedsiębiorstwach w Polsce i za granicą, Zarządzanie Przedsiębiorstwem 3, p. 17.

Gnojny-Zbierowska M. (2016) w artykule Znaczenie postrzegania organizacji przez pracownika we współczesnych naukach o zarządzaniu, Studia ekonomiczne. Zeszyty Naukowe Uniwersytetu Ekonomicznego w Katowicach, Nr 306

Griffin R.W (2002) Podstawy zarządzania organizacjami, Wydawnictwo Naukowe

Gunkel M., Schlaegel Ch., Rossteutscher T., Wolff B. (2015) The human aspekt of cross-border acquisition outcomes: The role of management practices, employee emotions and national culture, International Business Reviev, Jun, Vol. 24 Issue 3, p. 394-408.

Hambrick, D.C., Mason, P.A. (1984), "Upper echelons: the organization as a reflection of its top managers", Academy of Management Review, Vol. 9 No. 2, pp. 193-206. https://doi.org/10.5465/amr.1984.4277628

Handbook of Counselling in Organizations (1997) (edit by) M. Carrol, M. Walton, SAGE Publication, London, p. 3.

https://sjp.pwn.pl/szukaj/sprawno\%C5\%9B\%C4\%87\%20.html (16.10.2017)

Huovinen S., Pasanen M. (2010) Entrepreneurial and management teams: What makes the difference?

Interim Management - Nowość w zarządzaniu wiekiem i firmą - wydanie specjalne - materiały udostępnione przez Stowarzyszenie Interim Management

Inwestycja w kapitał ludzki z Interim Managerem - materiały udostępnione przez Firmę INWENTA Sp. z o.o.

Journal of Management and Organization; Lyndfield Vol. 16, Iss. 3, (Jul 2010): 436-453.

Kossek E. E., Ollier-Malaterre A., Dean Lee M., Pichler S., Hall D. T. (2016), Line managers' rationales for professionals' reduced-load work In embracing andambivalent organizations, Human Resource Management, Vol. 55, Issue 1, January/February, p. 143-171. https://doi.org/10.1002/hrm.21722

Kożusznik B. (1994), Zastosowanie psychologii w pracy menedżera w: Psychologia w pracy menedżera (red.) B. Kożusznik, Wydawnictwo Uniwersytetu Śląskiego, Katowice, p. 20.

Loi R., Hang-yue N., Foley S. (2006) Linking employees' justice perceptions to organizational commitment and intention to leave: The mediating role of perceived organizational suport, Journal of Occupational and Organizational Psychology , 79, 101-120. https://doi.org/10.1348/096317905X39657

MacFarlane Shore L., Tetrick L. E.,(1991) A construct validy study of the Survey of Perceived Organizational Support, Journal of Apphed Psychology, Vol. 76, No 5, 637-643. https://doi.org/10.1037/0021-9010.76.5.637

McFarlane L., Wayne S. and S. J. (1993) Commitment and Employee Behavior: Comparison of Affective Commitment and Continuance Commitment With Perceived Organizational Support, Journal of Applied Psychology, Vol. 78, No. 5, 774-780. https://doi.org/10.1037/0021-9010.78.5.774 
Oleksyn T. (2010) Zarządzanie kompetencjami. Teoria i praktyka, Oficyna Wolters Kluwer business, Warszawa

Oleksyn T. (2017) Zarządzanie zasobami ludzkimi w organizacji, Wolter Kluwer, Warszawa

PWN, Warszawa 2002

Rhoades L., Eisenberger R. (2002) Perceived Organizational Support. A Review of the Literature. Journal of Applied Psychology, Vol. 87, No 4, 698-714. https://doi.org/10.1037/0021-9010.87.4.698

Sawang S. (2010) Moderation or mediation? An examination of role perceived managerial support has on job satisfaction and psychological strain. Current Psychology 2010 29:247-256. https://doi.org/10.1007/s12144-010-9083-9

Stańczyk I. (2017) Perception of organizational suport by employees - results of research, 29 May 2017, 8th Economics \& Finance Conference, London, http://www.iises.net/pastconferences/economic/8th-economics-finance-conference-london/page-abstract-8th-economicsfinance-conference-london?article=perception-of-organizational-support-by-employees-results-ofresearch (26.06.2017)

Stańczyk I. (2018), Wsparcie organizacyjne menedżerów, Wydawnictwo Uniwersytetu Jagiellońskiego, Kraków

Torun A. (2013) Employee counselling and career development. International Journal of Business and Management, 1(1), p. 18-36.

Turek D., Czaplińska I. (2014) Praktyki ZZL, klimat organizacyjny i postrzeganie wsparcia menedżerskiego a zachowania obywatelskie pracowników, Organizacja i Kierowanie, 4 (164), s. 132.

Tuzun I. K., Kalemci R. A. (2012) Organizational and supervisory support in relation to employee turnover intentions, Journal of Managerial Psychology, Vol. 27 Iss: 5, pp. 518 - 534. https://doi.org/10.1108/02683941211235418

Tyrańska M. (2011), System oceny kompetencji menedżerskiej [w:] Przegląd problemów doskonalenia systemów zarządzania przedsiębiorstwem (red. nauk.) A. Stabryła Mfiles.pl Encyklopedia Zarządzania, Kraków

Wendt R., Niesiobędzka-Rogatko K., Dziewit-Gontowska U. Interim Management w Polsce. Raport z badania zrealizowanego w 2016 roku przez Stowarzyszenie Interim Managers - materiały udostępnione przez Stowarzyszenie Interim Management

Williams G. C., Halvari H., Niemiec Ch. P., Sørebø Ø., Olafsen A. H., Westbye C.,(2014) Managerial support for basic psychological needs, somatic symptom burden and work-related correlates: A self-determination theory perspective, Work \& Stress, Vol. 28, No. 4, 404 - 419. https://doi.org/10.1080/02678373.2014.971920

www.reinfuss.pl 